\title{
PENDEKATAN SAINTIFIK DALAM PEMBELAJARAN BAHASA ARAB DI MADRASAH IBTIDAIYAHBERBASIS KURIKULUM 2013
}

\author{
Anwar Sadat \\ Fakultas Tarbiyah IAI Muhammadiyah Bima \\ Email: anwarbinmalik@gmail.com
}

\begin{abstract}
Abstrak
Pendekatan dalam pembelajaran bahasa Arab memiliki peran penting dalam memandu jalannya proses pembelajaran khususnya bahasa Arab karena dari pendekatan semuanya harus dimulai, baik menentukan tujuan, materi, metode dan teknik pembelajaran harus terintegrasi dengan pendekatan yang digunakan. Berkaitan dengan hal tersebut, seiring dengan implementasi kurikulum 2013 di tingkat satuan pendidikan, proses pembelajaran bahasa Arab khususnya diMadrasah Ibtidaiyahjuga mengalami perubahan paradigma pembelajaran yang menekankanpendekatan saintifik (scientific approach) yakni mengandung lima elemen penting mencakup aktivitas mengamati, menanyakan, mengumpulkan informasi, mengasosiasi, dan mengkomunikasikan hasil pembelajaran.Kelima elemen ini harus digunakan secara integral-holistikdalamketrampilan membaca (mahârah qiraah), ketrampilan menulis (mahârah kitabah) kegiatanmenyimak (mahârahal-istima'), dan kegiataan berbicara (mahârah al-kalâm) sebagai fondasi dalam berbahasa. Sedangakan Pembelajaran qawâid (kaidah-kaidah) kebahasaan hanya diajarkan seperlunya yang berkaitan dengan cara menggunakan kata-kata ganti (dhamâir), kata-kata tanya (isim istifham), kata-kata tunjuk (isim isyarah) dan lain-lain.
\end{abstract}

Kata Kunci: Pendekatan Saintifik, Pembelajaran Bahasa Arab

\section{PENDAHULUAN}

$\mathbf{P}$ embelajaran bahasa Arab di Madrasah mulai dari satuan Madrasah Ibtidaiyah (MI), Madrasah Tsanawiyah (MTs) dan Madrasah Aliyah (MA) atau pondok pesantren memiliki kekhasan yang berbeda-beda. Baik dari segi pendekatan, materi, metode, teknik dan tujuan pembelajaran yang hendak dicapai. Lahirnya Kurikulum 2013 bertujuan untuk menyeragamkan perbedaan tersebut, Sehingga peserta didik menjadi manusia Indonesia yang memiliki kemampuan hidup sebagai pribadi dan warga Negara yang beriman, produktif, kreatif, inovatif, dan afektif serta mampu berkontribusi pada kehidupan bermasyarakat, berbangsa, dan peradaban dunia. (Permenag RI, 2013: 9).Untuk mendapatkan kemampuan tersebut di atas maka Sumber Daya Manusia (SDM) atau peserta didik dalam pembelajaran harus menggunakan pendekatan 
saintifikdengancaramengamati, menanya, mengeksplorasi, mengasosiasi dan mengkomunikasikan.Sehingga pembelajaran bahasa Arab berjalan dengan baik sesuai dengan tujuan dan kemampuan (mahârah) yang hendak dicapai yakni mendorong agar peserta didik memiliki kemampuan dasar berbahasa baik secara reseptif maupun produktif maupun bersikap positif terhadap bahasa Arab. Kemampuan reseptif yaitu kemampuan untuk memahami pembicaraan orang lain dan memahami bacaan. Sedangkan Kemampuan produktif yaitu kemampuan menggunakan bahasa sebagai alat komunikasi baik secara lisan maupun secara tertulis. Dengan kemampuan dasar berbahasa Arab dan memiliki sikap positif terhadapnya sangat membantu peserta didik memahami Alquran dan Hadis serta buku-buku berbahasa Arab.

Pembelajaran Bahasa Arab di Madrasah Ibtidaiyah dipersiapkan untuk pencapaian kompetensi dasar berbahasa, yang mencakup dua keterampilan berbahasa yang diajarkan secara integral, yaitu menyimak (mahâratu al-istima'), berbicara (mahâratu al-kalâm) sebagai fondasi dalam berbahasa. (Permenag RI, 2013: 37).Dengan duaal-Mahârah(keterampilan) itu siswa memiliki tiga dimensi dan kualifikasi kemampuan dalam dirinya. Dimensipertama; dimensi sikap (mauqif), kedua; dimensi pengetahuan(ma'rifah), ketiga; dimensiketerampilan (kafaah). Sedangkan kualifikasi yang akan didapatkan oleh pesertadidik yang pertama; memiliki perilaku yang mencerminkan sikap orang beriman, berakhlak mulia, berilmu, percaya diri, dan bertanggung jawab dalam berinteraksi secara efektif dengan lingkungan sosial dan alam di lingkungan rumah, sekolah, dan tempat bermain, kedua; Memiliki pengetahuan faktual dan konseptual berdasarkan rasa ingin tahunya tentang ilmu pengetahuan, teknologi, seni, dan budaya dalam wawasan kemanusiaan, kebangsaan, kenegaraan, dan peradaban terkait fenomena dan kejadian di lingkungan rumah, sekolah, dan tempat bermain, ketiga; Memiliki kemampuan pikir dan tindak yang produktif dan kreatif dalam ranah abstrak dan kongkret sesuai dengan yang ditugaskan kepadanya.

Dengan adanya pendekatan saintifik dapat memudahkan guru dan siswa dalam belajar dan memahami pembelajaraan bahasa Arab sebab dengan pendekatan ini kaidah-kaidah (tarkîb) kebahasaan hanya diajarkan yang bersifat pragmatis-praktis misalnya ketepatan menggunakan kata tunjuk (isim isyarah) dengan benda yang ditunjuk (musyar ilaihi $)^{1}$, kata-kata ganti dengan kata benda

\footnotetext{
هذا عمر, هذه فاطمة, ذلك رضوان, تلك عائشة, هذه غرفة, هذا مسجد, ذلك مدرس, تلك مدرسة, هذه شأ حديقة, هذا بيت, ونحو ذلك
} 
(isim) yang sesuai ${ }^{2}$, angka-angka (adadun) dengan yang diangkai (ma'dud), mengungkapkan pertanyaan (istifham) dengan yang ditanyai.(Menteri Agama RI, 2014: 8).

\section{Pengertian Pendekatan Saintifik}

Dalam pembelajaran bahasa Arab pendekatan memiliki peran yang sangat penting dalam memandang bahasa atau mengajarkan bahasa kepada peserta didik.Tanpa pendekatan pembelajaran tidak memiliki orientasi yang jelas. Menurut Wa Muna (2011: 12)pendekatan adalah seperangkat asumsi mengenai hakekat bahasa yang bersifat aksiomatik. Pandangan senada juga dikemukakan oleh M. Abdul Hamid (2018:2) dkk.,yang menyatakan pendekatan adalah seperangkat asumsi-asumsi yang antara satu dengan saling berkaitan. Asumsi ini sangat erat kaitannya dengan karakter dan sifat bahasa dalam prose pengajaran dan pembelajaran.

Sedangkan Asep Hermawan (2013: 167)berpendapat pendekatan adalah sekumpulan asumsi tentang proses belajar mengajar yang dalam bentuk pemikiran aksiomatisyang tak perlu diperdebatkan lagi. Dengan kata lain pendelatan merupakan pendirian filosofis yang selanjutnya menjadi acuan dalam kegiatan belajar mengajar bahasa.Misalnya ada yang berpendapat bahwa bahasa lahir sesuatu yang didengar diucapkan, sedangkan menulis merupakan kemampuan yang muncul sesudahnya.Dari pendapat ini lahirlah asumsi-asumsi yang menyatakan bahwa tahap awal yang harus dilakukan dalam mengajar bahasa adalah menanamkan kemampuan mendengar (istima') dan berbicara(kalâm). Setelah itu belajar mengajar untuk menanamkan kemampuan membaca (qira'ah) dn menulis (kitâbah). Dalam bahasa Arab pendekatan disebut المدخل/approach artinya tempat masuk. Kata ini berasal fi'il madhi (kata kerja lampau) /dakhalayang berarti masuk kemudian dibentuk menjadi isim makân(keterangan tempat).

Dari berbagai sudut pandang tentang pengertian pendekatan tersebut di atas bahwa pendekatan memiliki beberapa unsur antara lain, pertama; pendekatan bersifat folosofis, kedua; Pendekatan bersifat bersifat aksiomatis, ketiga; pendekatan berfungsi menjadi acuan dalam proses pembelajaran. Dikatakan bersifat filosofis, karena pendekatan ibarat kompas dalam menentukan arah pembelajaran bahasa, ia bersifat aksiomatis karena pendekatan dalam prsoses belajar sangat penting dan sudah menjadi kesepakatan umum bahwa pendekatan

أنتَّ رجل, انتِ طالبة, هو مهندس, هى طبيبة, هم طلاب, هنَ طالبات, هما أستذان, أنا مدرس, نحن الأساتذ2Misalnya kata 
dalam proses belajar mengajar wajid ada dan harus ada. Pendirian ini menjadi kesepakatan umum para pakar pendidikan tanpa ada pendekatan maka pembelajaran tidak memiliki orientasi yang jelas. Oleh sebab itulah, ia harus ada dan diterapkan dalam aktivitas belajar mengajar.

\section{Pendekatan Saintifik Dalam Pembelajaran Bahasa Arab.}

Pada kurikulum 2013 pendekatan yang digunakan dalam pembelajaran bahasa Arab Madrasah khususnya Madrasah Ibtidaiyah adalah pendekatan saintifik (al-Madkhal al-Ilmi/scientifc approach). Pendekatan ini yang terangkum dalam proses mengamati, menanya, mengeksplorasi, mengasosiasi dan mengkomunikasikanatau dengan kata lain pembelajaran dengan menggunakan pendekatan saintifik harus memerhatikan komponen-komponen penting berikut ini:

1. Menyajikan pembelajaran yang dapat meningkatkan rasa keingintahuan (Foster a sense of wonder)

2. Meningkatkan keterampilan mengamati (Encourage observation)

3. Melakukan analisis (Push for analysis) dan

4. Berkomunikasi (Require communication).

Dari keempat komponen tersebut di atas dapat dijabarkan kedalam lima bentuk praktek pembelajaran sebagai berikut:

\begin{tabular}{|c|c|}
\hline Komponen Saintifik & Instumen Uraian \\
\hline Mengamati & $\begin{array}{l}\text { Kegiatan belajaran yang dapat dilakukan pesertadidik } \\
\text { misalnya membaca, mendengar, menyimak,melihat } \\
\text { (dengan atau tanpa alat). Kompetensi yangingin } \\
\text { dikembangkan melalui pengalaman belajarMengamati } \\
\text { adalah melatih kesungguhan,ketelitian, dan } \\
\text { kemampuan mencari informasi }\end{array}$ \\
\hline Menanya & $\begin{array}{l}\text { Kegiatan belajar yang dapat dilakukan adalah } \\
\text { mengajukan pertanyaantentang informasi } \\
\text { apaPendekatan Pembelajaran Saintifik yang tidak } \\
\text { dipahami dari apa yang diamati ataupertanyaan untuk } \\
\text { memperoleh informasitambahan tentang apa yang } \\
\text { sedang mereka amati.Pertanyaan yang peserta didik } \\
\text { ajukan semestinyadapat dimulai dari pertanyaan- } \\
\text { pertanyaan yangbersifat faktual saja hingga mengarah } \\
\text { kepadapertanyaan-pertanyaan yang sifatnya } \\
\text { hipotetik(dugaan). Kompetensin yang dikembangkan } \\
\text { adalahpengembangan kreativitas, rasa ingin } \\
\text { tahu(curiousity), kemampuan merumuskan } \\
\text { pertanyaanuntuk pengembangan keterampilan berpikir }\end{array}$ \\
\hline
\end{tabular}




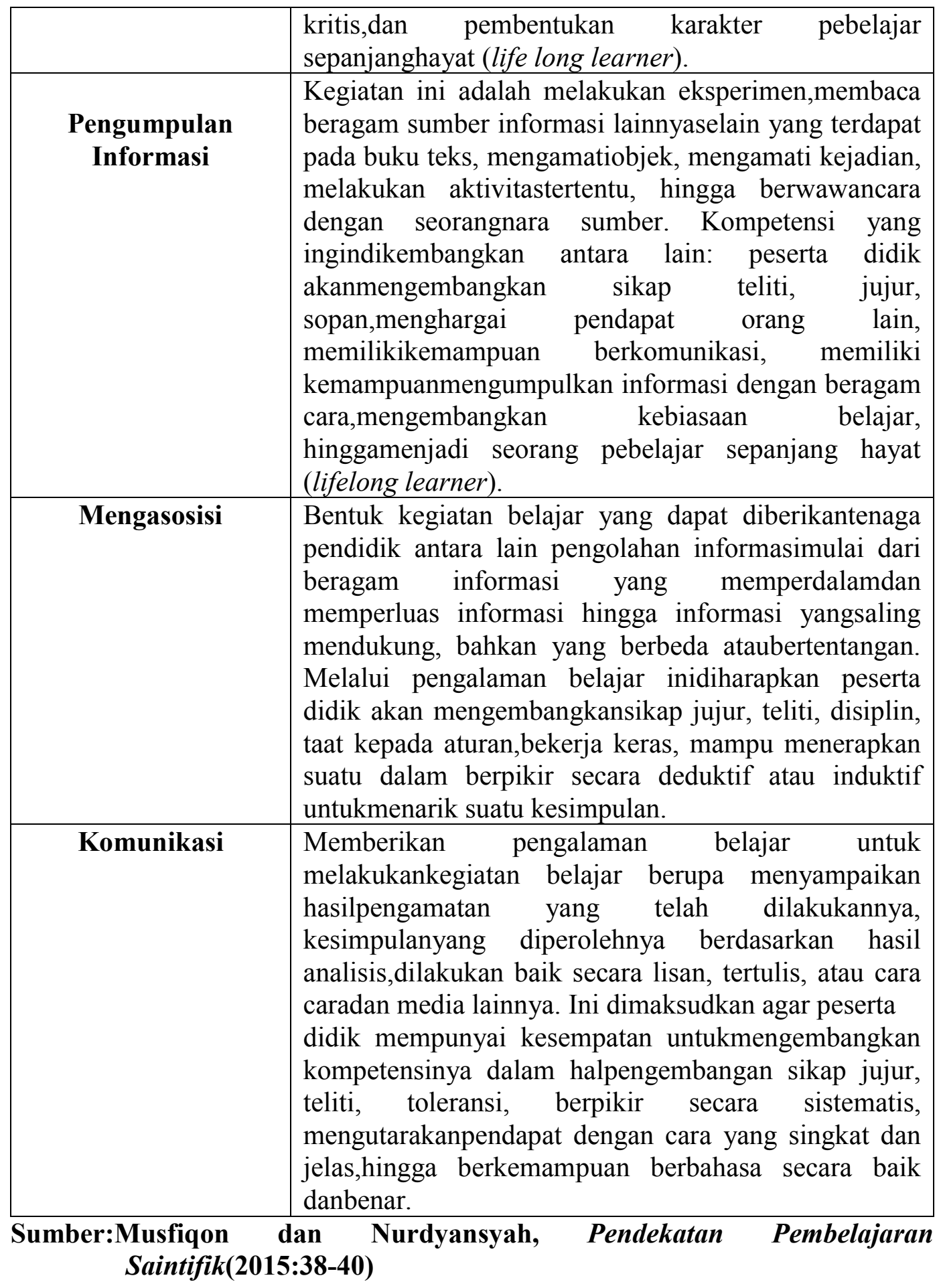

Dari lima langkah model pendekatan saintifik ini dapat digunakan secara berurutan maupun tidak berurutan tergantung pada situasi dan kondisi dan isi pokok materi pembelajaran yang dipelajari. Dalam pembelajaran bahasa Arab kelima model tadi dapat diuraikansebagai berikut: 


\section{Kegiatan Mengamati}

Dalam kegiatan pengamatan ini guru harus melakukan langkah-langkah sebagai berikut:

a. Guru meminta peserta didik mengamati gambar terkait topik gambar yang dipelajari.

b. Guru membacakan kosakata terlebih dahulu kemudian guru mengarahkan pesertadidik untuk memperhatikan kosakata yang tersedia, lalu mulai membacakosakata, ungkapandemi ungkapan sementara peserta didik terus memperhatikan materipelajaran.

c. Membaca dan menirukan. Guru membaca kosakata, lalu memberi aba-aba kepada peserta didik untuk menirukan, maka semuanya mengulangibacaan guru. Demikian seterusnya sampai kosakata terakhir.

d. Membaca perindividu dengan suara keras dan jelas. Guru memintabeberapa siswa satu persatu untuk membaca kosakata dengan peserta didik lainnya.

e. Menjelaskan arti kata. Guru menjelaskan arti tiap kosakata denganmemberikan contoh fisik, seperti gambar, atau benda-benda sekitar, ataualat peraga yang telah disiapkan. Dan untuk memastikan bahwa pesertadidik telah paham, dapat dilakukan terjemah. (Menteri Agama RI, 2014: 2).

f. Gambar-gambar yang dimaksud adalah sebagai berikut;

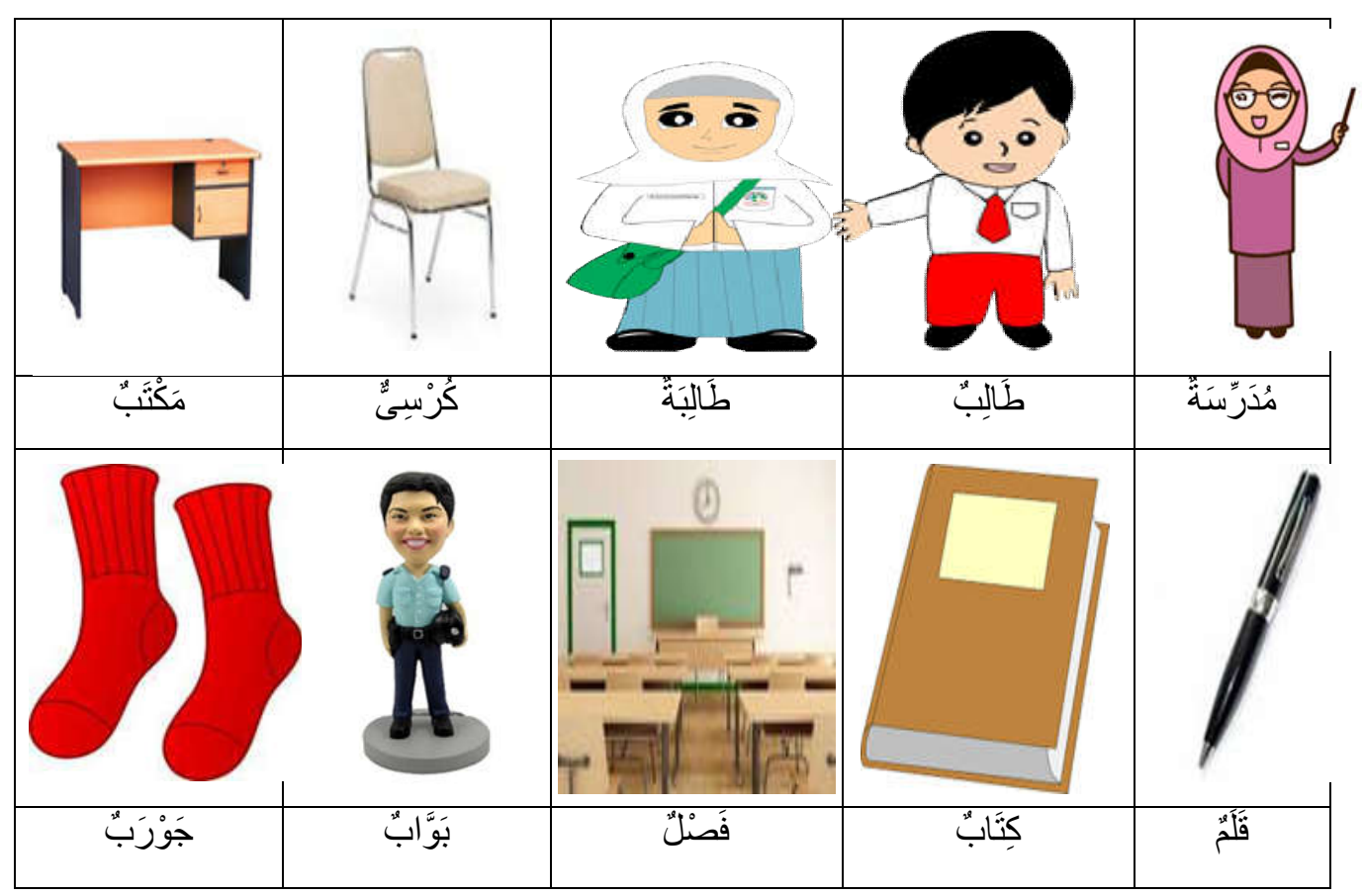




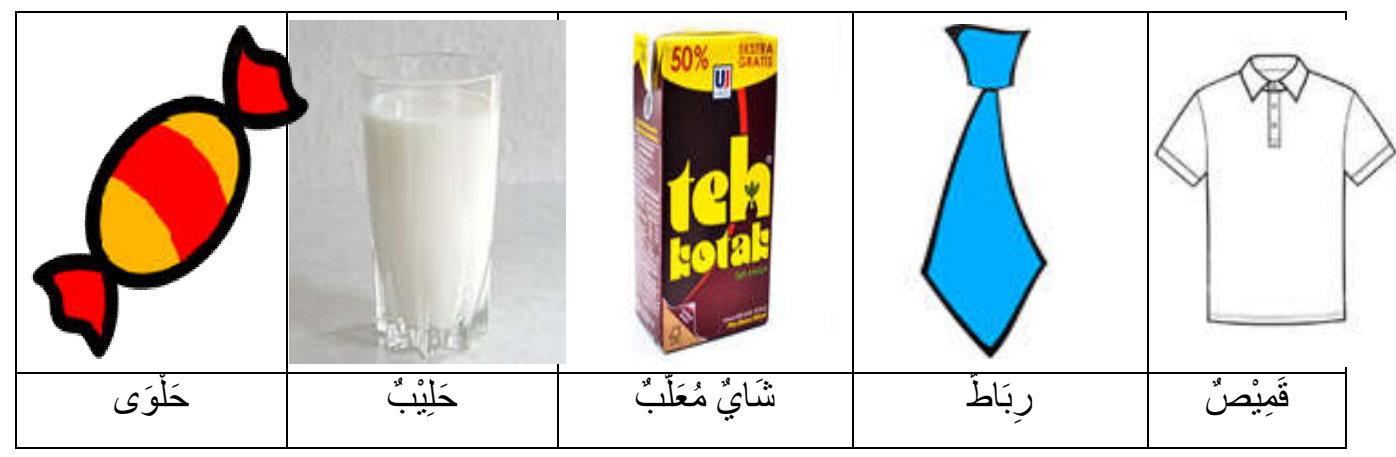

Setelah guru memperlihatkan gambar-gambar di atassatu persatu lewat slide, apabila telah dipahami oleh siswa maka dilanjutkan dengan kegiatan bertanya.

\section{Kegiatan Bertanya}

Setelah guru memperlihatkan gambar-gambar tersebut beserta menerjemahkan kedalam bahasa Arab, maka guru melanjutkan kegiatan pembelajaran bahasa Arab dengan kegiatan tanya jawab dengan gambar tersebut.Pada saat melakukan tanya jawab guru menggunakan kata-kata tanya berikut ini;

a. Gunakan tanya jawab dengan pertanyaan(من هذا؟)dan jawaban|هذا؟)...atau من (هذه:dan jawabannya (...) yang sesuai dengan gambar (Menterian Agama RI, 2015: 10). Adapun bentukanya, dapat diperhatikan contoh gambar berikut ini;

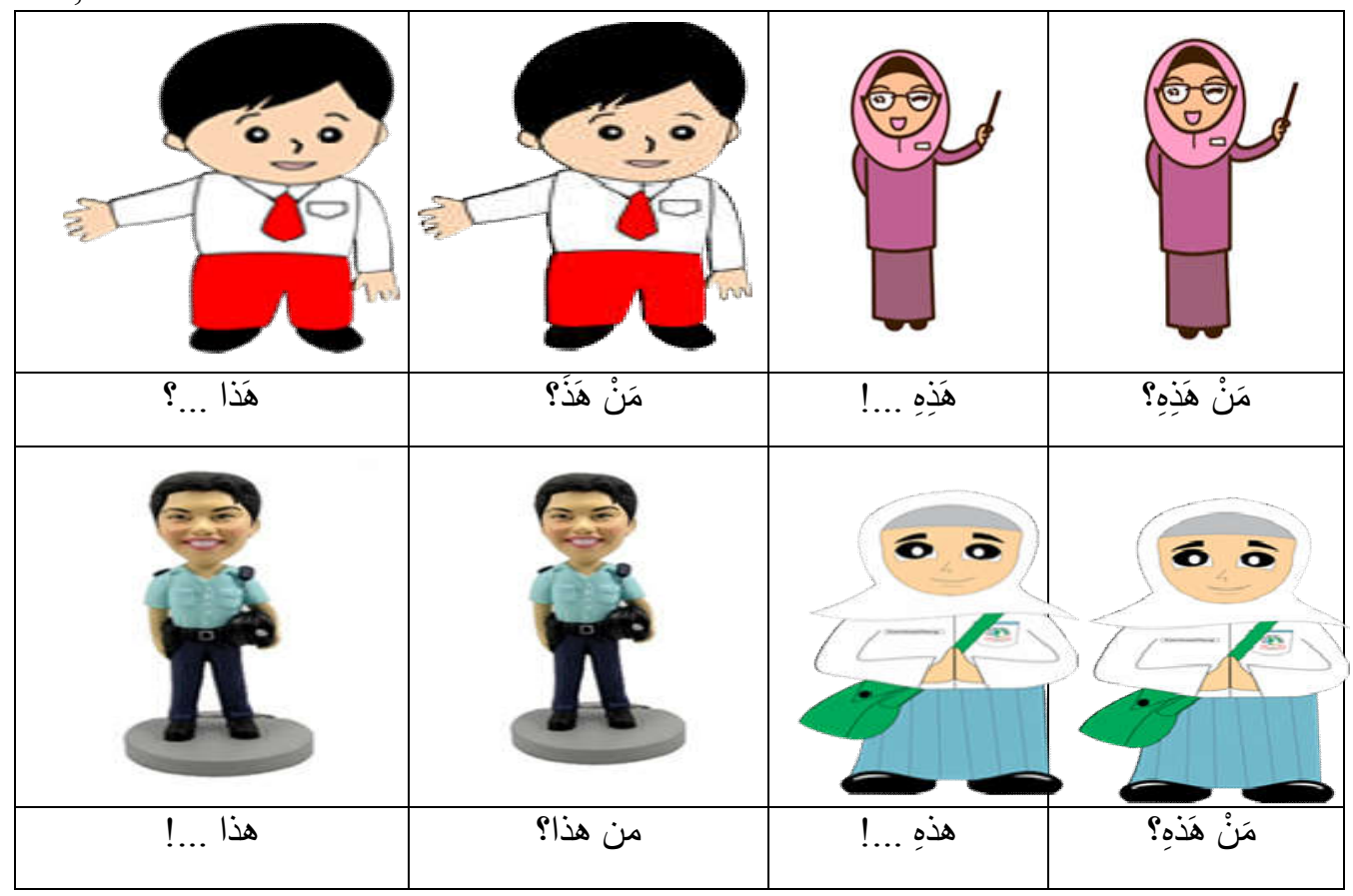


b. Gunakan tanya jawab dengan pertanyaan (؟....

Selanjutnya guru menggunakan kata tanyamâ (apa) yang sesuai dengan gambar. Pada tahap ini guru memperlihatkan gambar-gambar dengan menggunakan slide kemudian bertanya dan siswa menjawab sesuai dengan gambar yang diperlihatkan seperti gambar berikut:

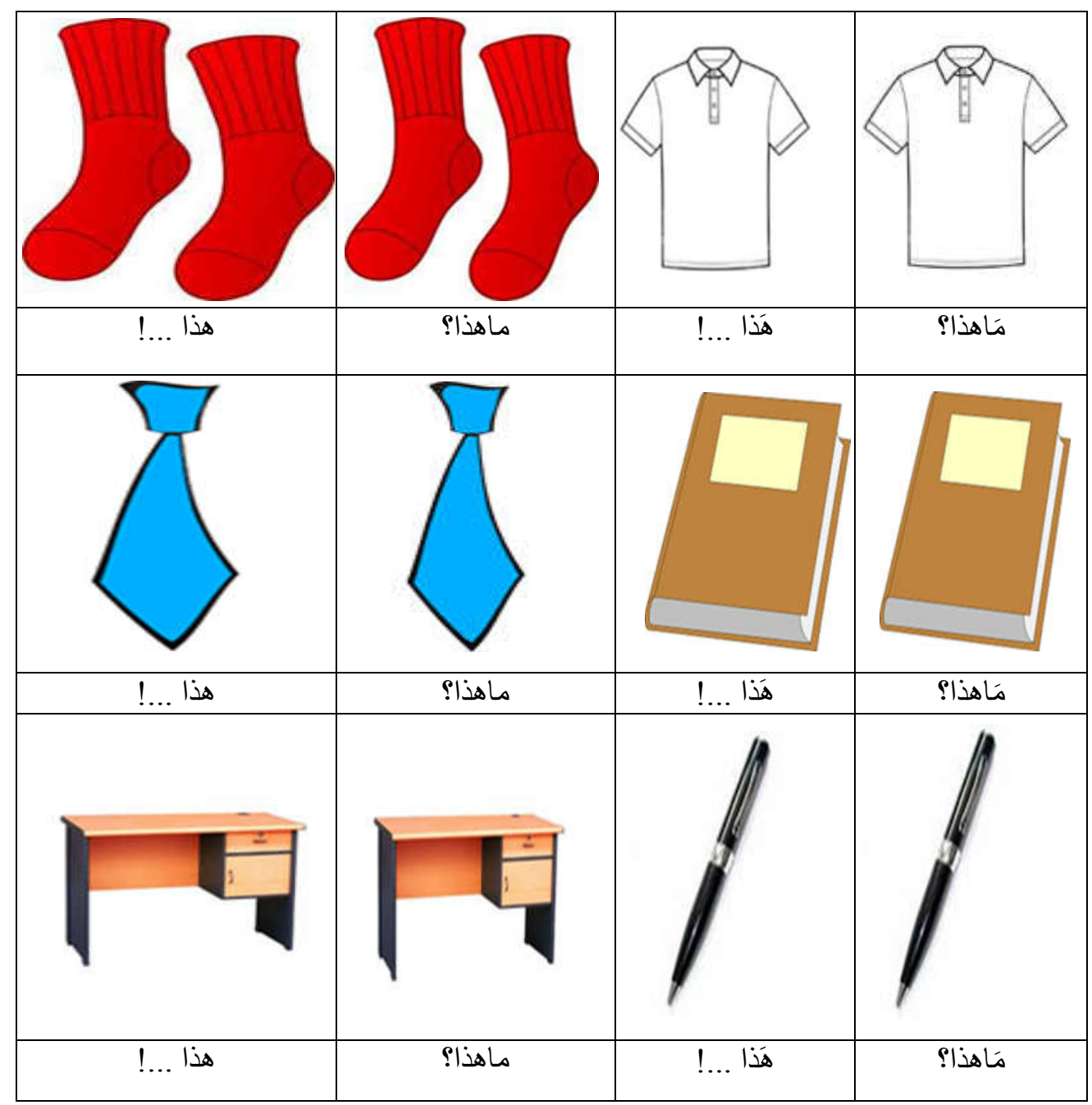

Pertanyaan itu sebaiknya diberikan kepada seluruh peserta didik agar katakata benda dan cara menjawabnya terekam dalam memori mereka. Setelah kegiatan ini telah selesai selanjutnya guru menyuruh siswa membaca pertanyaan

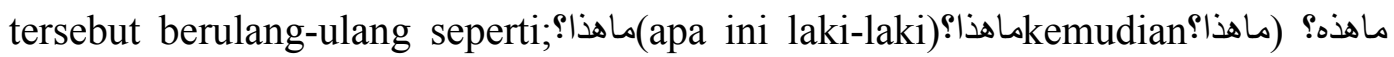
(apa ini PR),) ماهذه؟ ما هذه؟من هذا؟ هذا؟ من هذا؟؟)(siapa ini lkemudian

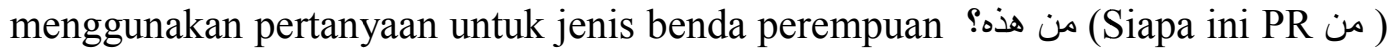
هذه؟ من هذه؟ 
c. Gunakan tanya jawab dengan pertanyaan أين ... (dimana)

Sebelum menggunakan pertanyaan ini guru memperlihatkan gambarberikut ini lewat slide kemudian siswa memerhatikan secara seksama.

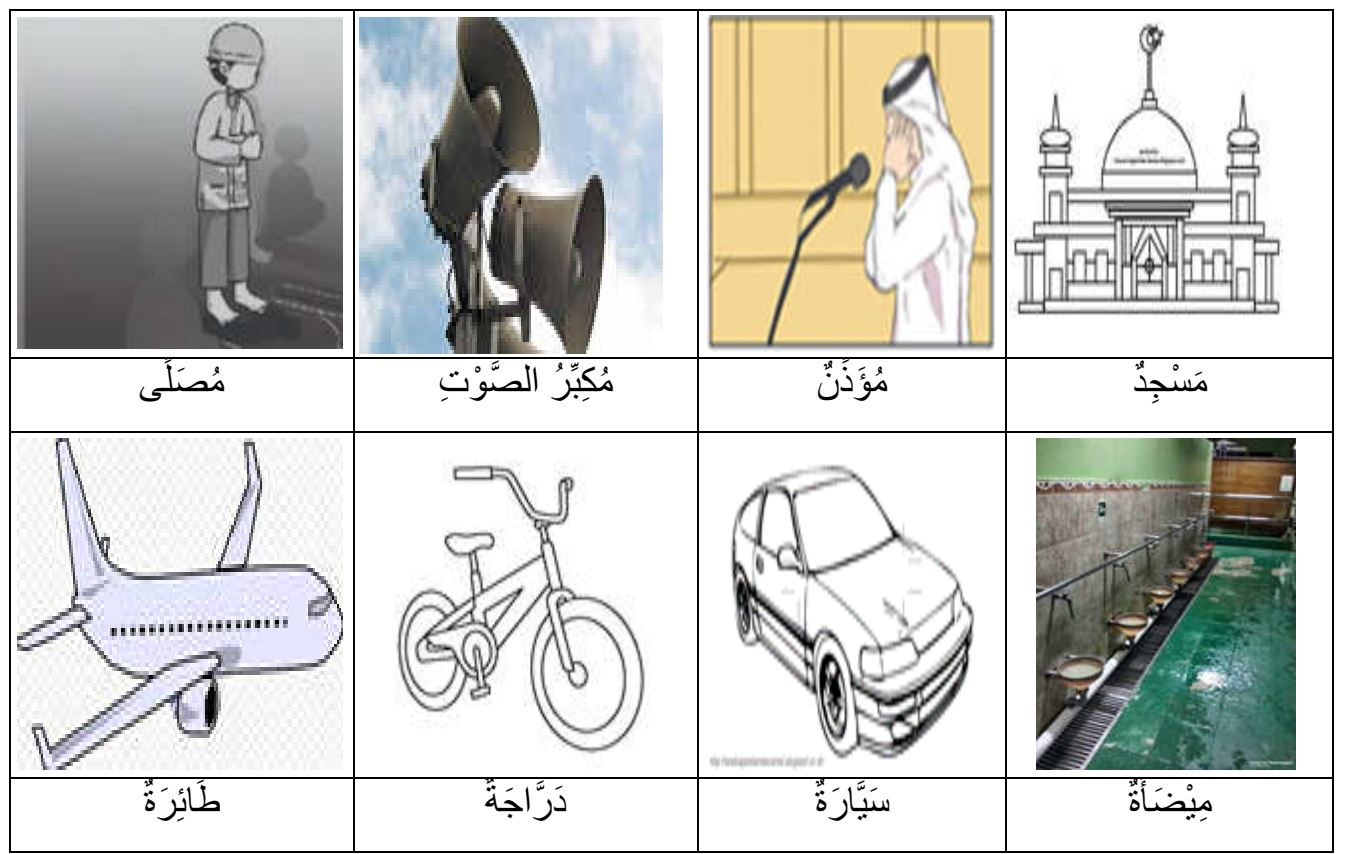

Kemudian guru bertanya kepada siswa dengan menggunakan pertanyaan aina (dimana) dan siswa menjawab pertanyaan guru berdasarkan gambar yang sesuai yang telah ditunjuk oleh guru.

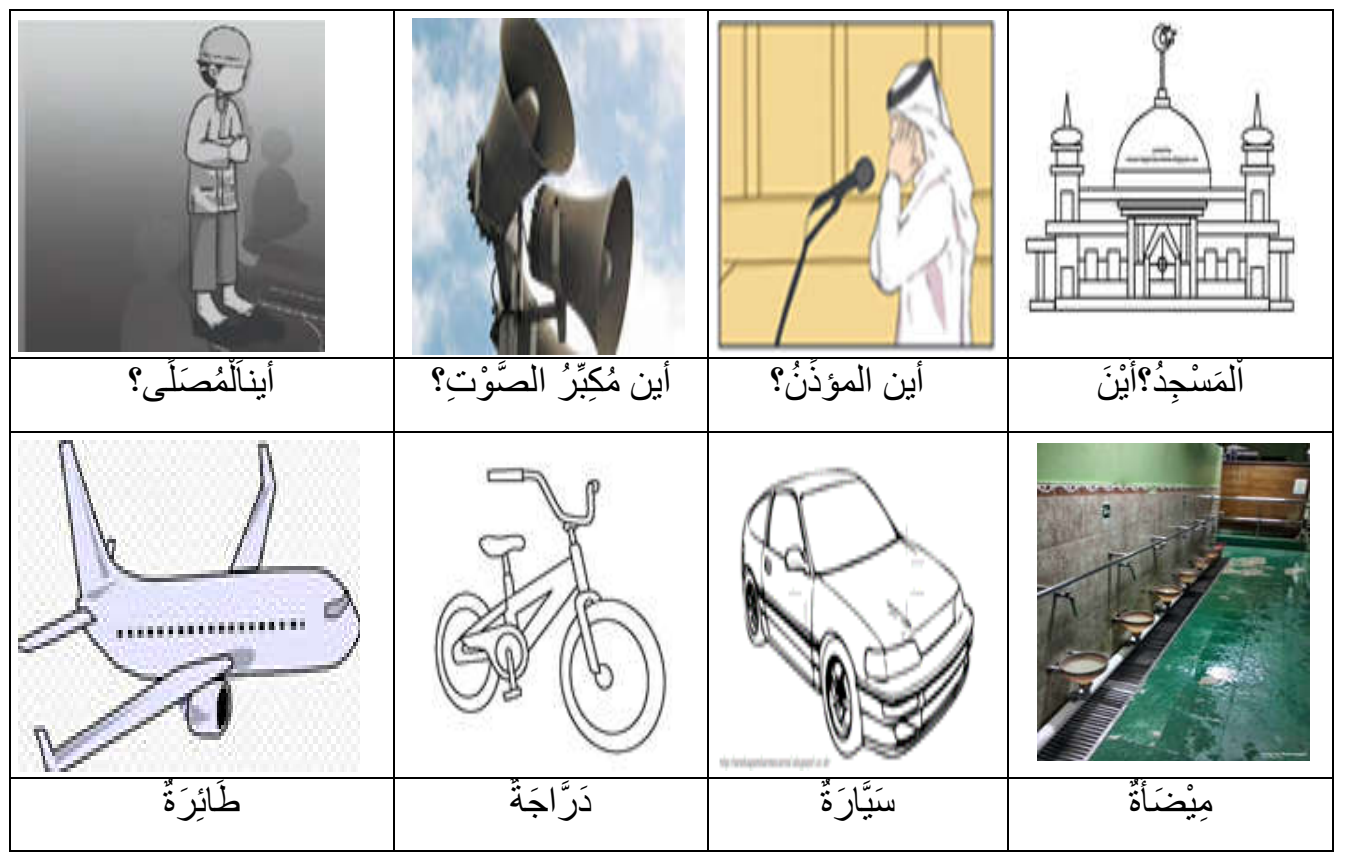

Pertanyaan ini biasanya digunakan untuk menanyakan letak atau posisi suatu benda, baik yang mudzakar (benda yang dihukumi laki-laki) maupun yang 
muannas (benda yang dihukumi perempuan). Artinya pertanyaan ini berfungsi ganda, dengan demikian kata tanya dalam bahasa Arab tidak memiliki perbedaan dalam konteks penggunaannya. Untuk melatih kemampuan daya ingat siswa terhadap kosa kata yang telah diperlihatkan dan dialogkan tersebut, maka guru mengulang kembali dengan cara menyebut kata yang dirinci kedalam huruf-huruf, baik huruf diawal kalimat, tengah maupun diakhir. (Menterian Agama RI, 2015: 47).Perhatikan contoh berikut ini:

\begin{tabular}{|c|c|c|}
\hline جִجُجُ & جَجَج & \multirow[t]{2}{*}{ اج } \\
\hline جِيْجُجْ جُوْ & جَاجَا جِىْ & \\
\hline ذِذِذَ & ذَذَذِ & \multirow[t]{2}{*}{$\dot{j} / \mathrm{dz}$} \\
\hline 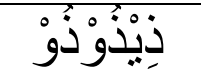 & ذَاذَاذِيْ & \\
\hline كَّ لكُ كُ كُ & كَكَ كََ كََ & \multirow[t]{2}{*}{ 5) $/ \mathrm{k}$} \\
\hline كِيْكِيْكُوْ & كَا كَا كَا & \\
\hline عِ مُ مُ مُ & مَ & \multirow[t]{2}{*}{$\mathrm{r} / \mathrm{m}$} \\
\hline مِيْمُوْهُوْ & مَا ماً مِيْ & \\
\hline طِطَط & طُطَطِ & \multirow[t]{2}{*}{ b/th } \\
\hline طِيْطُوُْوْ & طَا طَا طِين & \\
\hline تتِتِ تُ & تَتَتَتَ & \multirow[t]{2}{*}{$ت / \mathrm{t}$} \\
\hline 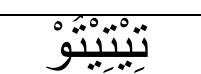 & تَُاتَّانَّا & \\
\hline
\end{tabular}

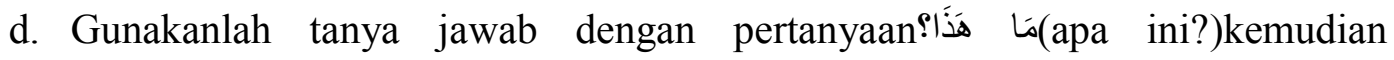

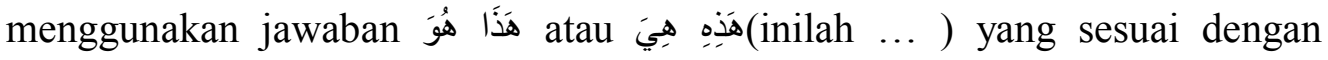
gambar yang ditunjuk.Agar terjadi hiwâr (dialog) antara siswa dengan guru atau siswa dengan guru, maka memberikan contoh sangatlah tepat sebelum memulai pembelajaran. Perhatikan contoh berikut; 


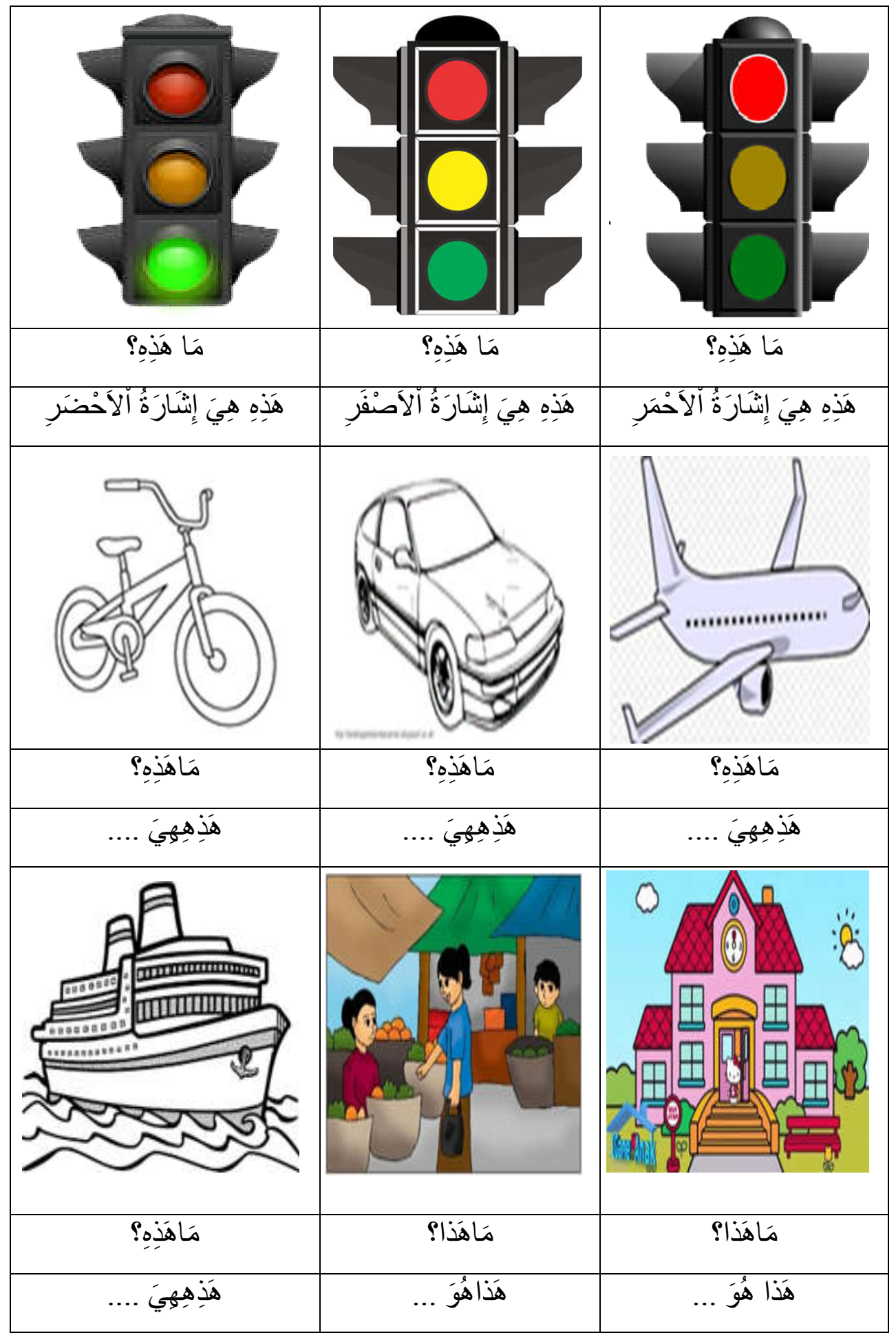

Setelah diberikan contoh oleh guru, siswa diperintahkan satu persatu oleh guru untuk menjawab pertanyaan yang sesuai dengan jenis benda yang ditanyakan. 


\section{Kegiatan Mengumpulkan Informasi}

Setelah melewati tahap pertama dan kedua, maka langkah selanjutnya dalam pendekatan saintifik adalah pengumpulan informasi yang hendak dipelajari.Pembelajaran bahasa Arab pada tahap ini, langkah-langkah yang harus dilakukan adalah sebagai berikut;

a. Guru membacakan perkosakata,peserta didik menyimak.

b. Peserta didik mencoba melafalkan kosakata perkata berdasarkan gambar yang ada bersama -sama dengan guru

c. Peserta didik mencoba menghafalkan makna mufradat berdasarkan gambar yang ada.

d. MengasosiasiBerikan klarifikasi terhadap hasil kerja kelompok tersebut. (Kementrian Agama RI, 2014: 26).

Dengan kegiatan ini siswa diharapkan memahami pengetahuan faktual dengan cara mengamati, mendengar,melihat, membaca dan menanyaberdasarkan rasa ingin tahu tentangdirinya, makhluk ciptaan Tuhan dankegiatannya, dan benda-benda yangdijumpainya di Rumah dan di Sekolah. (Kementrian Agama RI, 2014: 26). Pada tahap ini siswa agar disuruh membaca teks bahasa Arab yang telah dipersiapkan oleh guru. Teks yang diberikan hendaknya berkaitan dengan hal-hal yang mudah dijumpai atau yang lebih dekat dengan lingkungan peserta didik. Teks itu bisa berupa المهنة(profesi).Bacalah bacaan dibawah ini dengan seksama.

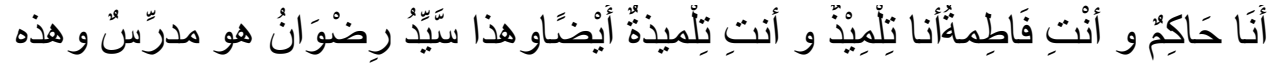

$$
\begin{aligned}
& \text { سيدة حَسَنَةُ هى مُدرسةٌ أيضًا أنْظري باَفاطمةُ ذلك حمدانُ هو موظف و ذلك أحمد }
\end{aligned}
$$

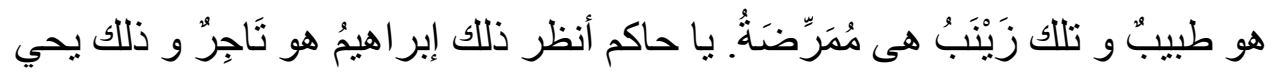

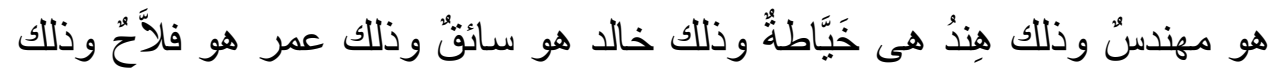

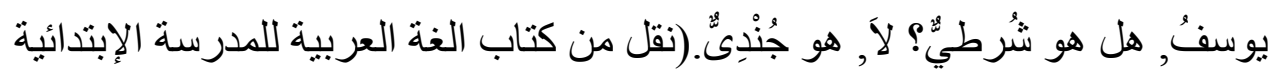

$$
\begin{aligned}
& \text { فصل رابع, ص. 32). }
\end{aligned}
$$

Untuk menggali isi teks di atas guru memberikan tugas kepada peserta didik berupa pertanyaan yang berkaitan dengan bacaan tadi. Contoh pertanyaan yang diberikan seperti di berikut ini; 


$$
\begin{aligned}
& \text { 1. مَنِ السيَيِّدُ رضوان؟ }
\end{aligned}
$$

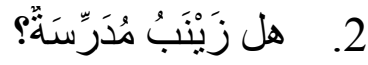

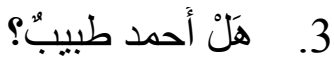

$$
\begin{aligned}
& \text { 4. هل عمر مدرّسُّ هل } \\
& \text { 5. مَنْ يُوْنُفُ؟ْ }
\end{aligned}
$$

Pertanyaan tadi dijawab secara kelompok atau secara individu oleh peserta didik yang dibimbing oleh guru. Setelah semua pertanyaan dikerjakan, selanjutnya guru melanjutkan kegiatan pembelajaran dengan melafalkan dan menghafal isim (kata benda) yang berkaitan dengan profesi.

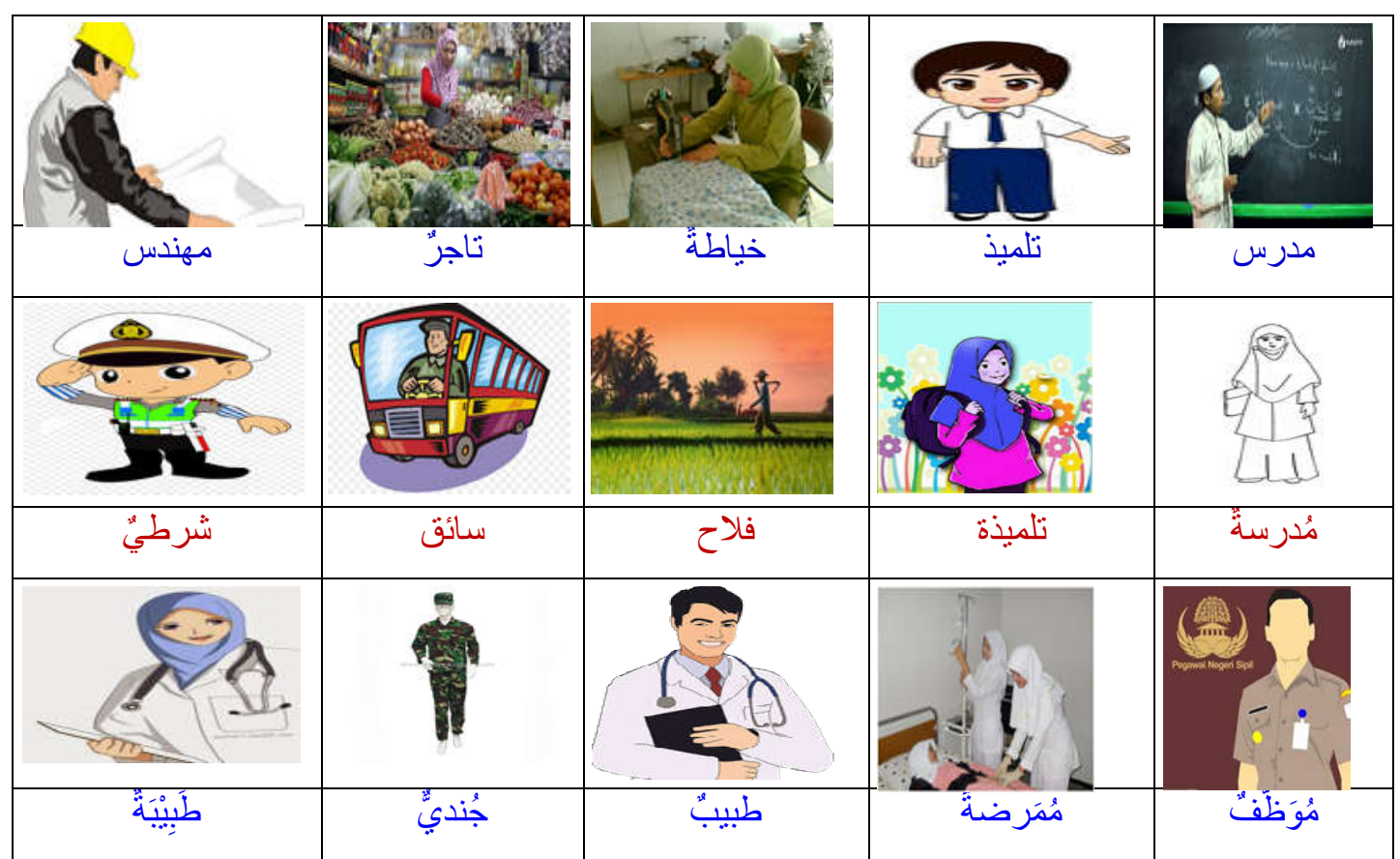

Agar mufradât (kosakata) ini bisa dihafal dengan baik oleh peserta didik, sebaiknya guru mengulang dengan cara menghubungkannya dengan dhamir (kata

\begin{tabular}{|c|c|c|c|c|c|c|c|c|c|}
\hline فَلَّمُ & هُهُ & تاجر" & هُوَ' & مهندسّ & هُوَ' & تِلِلميذٍ & هُهُ & مُدرِّسّ & هُهُ \\
\hline مُوَظْفَ & هُوَّ & جُنديُّ & هُوَ' & طبيبٌ & |هُوَ & شُرطيُ & هُهُو & سَائقُ" & هُهُ \\
\hline طَيْينَة: & هِيًَ & خَيَّاطة & هِيَ & تلميذةٌ & هِيَ & مُدرِّسة & هِيَّ & مُمَرِّرضة & هِيَّ \\
\hline
\end{tabular}
ganti), misalnya;

Penyebutan kosa kata yang berulang-ulangakan melekat dalam memori peserta didik. Pada waktu tertentu akan diproduksi kembali sesuai stimulus yang diberikan oleh guru. 


\section{Kegiatan Mengasosiasi}

a. Peserta didik menghafalkan makna mufradat sesuai dengan topik secara individual.

b. Peserta didik mempraktekkan untuk mempersilakan kepada temannya (lakilaki/perempuan) dengan kalimat perintah.

c. Peserta didik dapat memasangkan gambar tentang makanan atau minuman dalam kantin sesui dengan mufradatnya(tugas individu) atau gambar-gambar peralatan kantor atau sekolah.

Perhatikanlah gambar berikut ini;

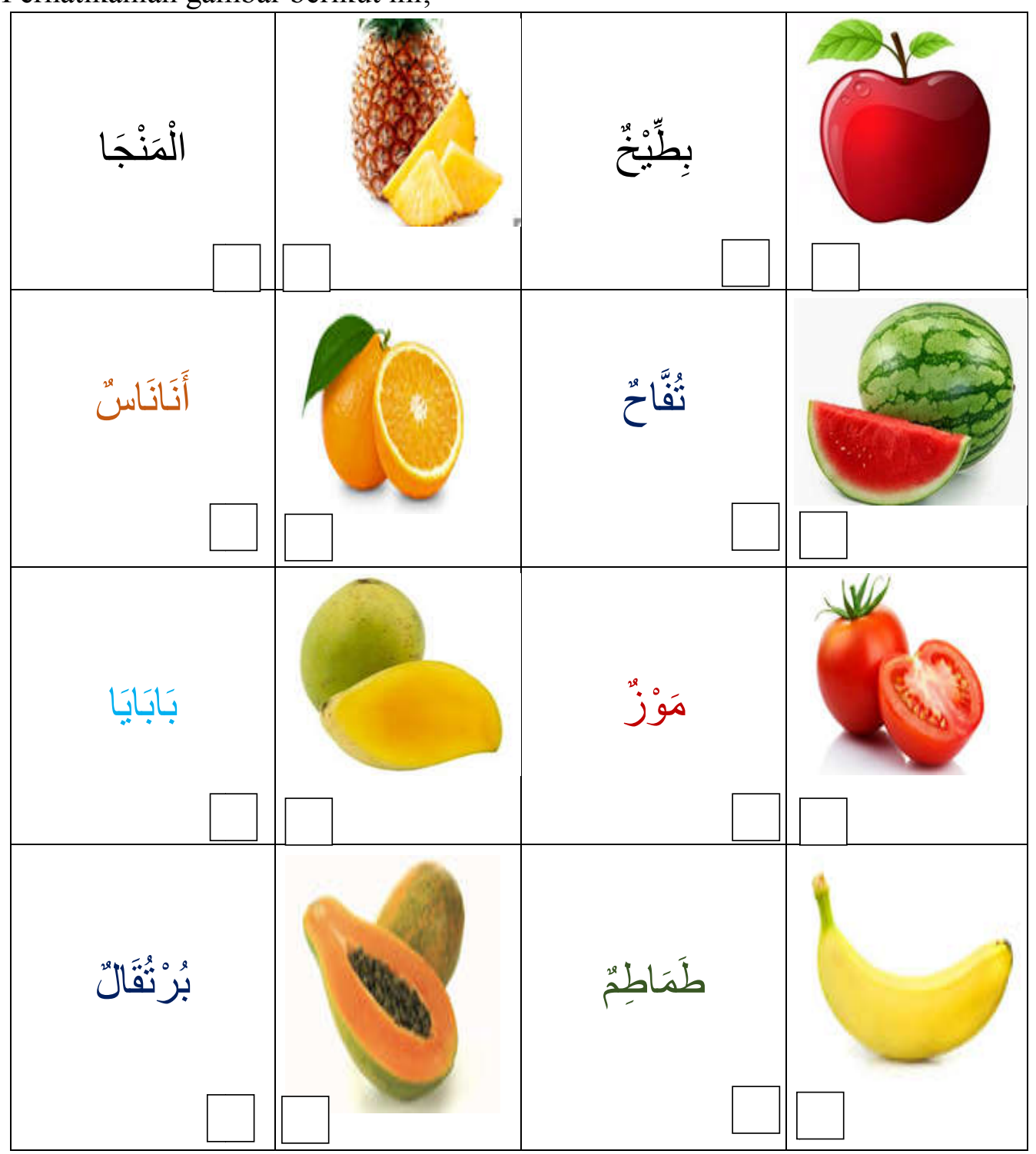

Makna gambar tersebut tidaklah tepat, tugas guru selanjutnya adalah memerintahkan peserta didik agar mencocokkan arti kata dengan gambar dengan 
cara memasukan nomor yang sesuai dengan arti kata sebagaimana contoh tersebut. Cara ini untuk menguji pemahaman siswa terhadap makna kata yang telah mereka pelajari atau yang telah dibacakan oleh guru di depan kelas. Setelah latihan selesai, guru dan siswa bersama-bersama membaca berulang-ulang kosa kata tadi. Perhatikan contoh berikut;

\begin{tabular}{|c|c|c|c|c|c|}
\hline ذلك/هذا & ذَلك/هذ| & 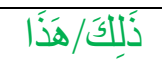 & تللك/هذه & تللك/هذه & تَلَّلَكَ/هَذَذِ \\
\hline شُـاي & 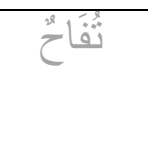 & 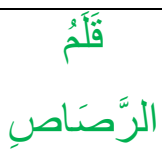 & مِبْرَاةُ & مِدَْاةُ & مِنْطَرَةُ \\
\hline $\begin{array}{l}\text { Itu/Ini } \\
\text { The }\end{array}$ & $\begin{array}{c}\text { Itu/Ini } \\
\text { Apel }\end{array}$ & $\begin{array}{l}\text { Itu/Ini } \\
\text { Pensil }\end{array}$ & $\begin{array}{c}\text { Itu/Ini } \\
\text { Peruncing } \\
\text { pulpen }\end{array}$ & $\begin{array}{c}\text { Itu/Ini } \\
\text { Penghapus }\end{array}$ & $\begin{array}{c}\text { Itu/Ini } \\
\text { Penggaris }\end{array}$ \\
\hline
\end{tabular}

Kosa kata yang ditunjuk harus disertai gambar atau fisik suatu benda supaya langsung bisa diamanati oleh peserta didik.

\section{Kegiatan Mengkomunikasikan}

a. Guru bersama peserta didik mencocokkan hafalannya sesuai dengan topik yang ada secara klasikal.

b. Guru dan peserta didik mengevaluasi praktek menggunakan kata perintah ... تَفَضَّلَ... تَفَضَّنَّي

c. Guru bersama peserta didik mengkomunikasikan hasil kerja memasangkan gambar denga mufradât.

d. Guru memberikan penguatan tentang materi yang telah dipelajari.Agar kegiatan komunikasi berjalan lancar siswa diperintahkan mengamati gambargambar seperti berikut ini;
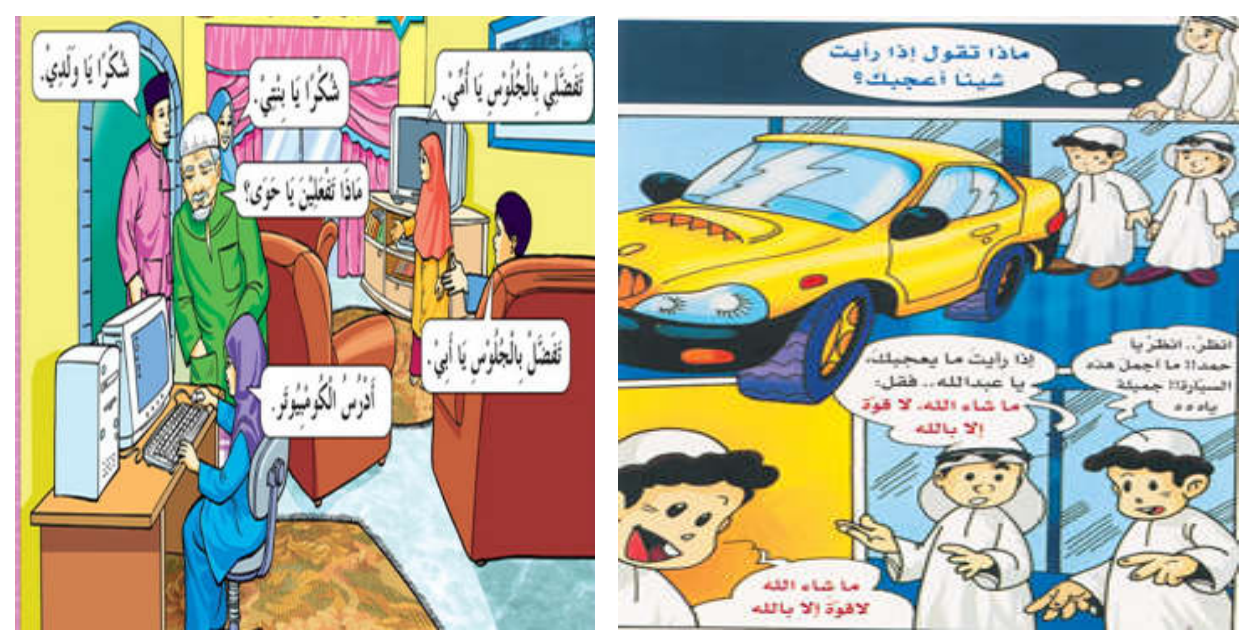

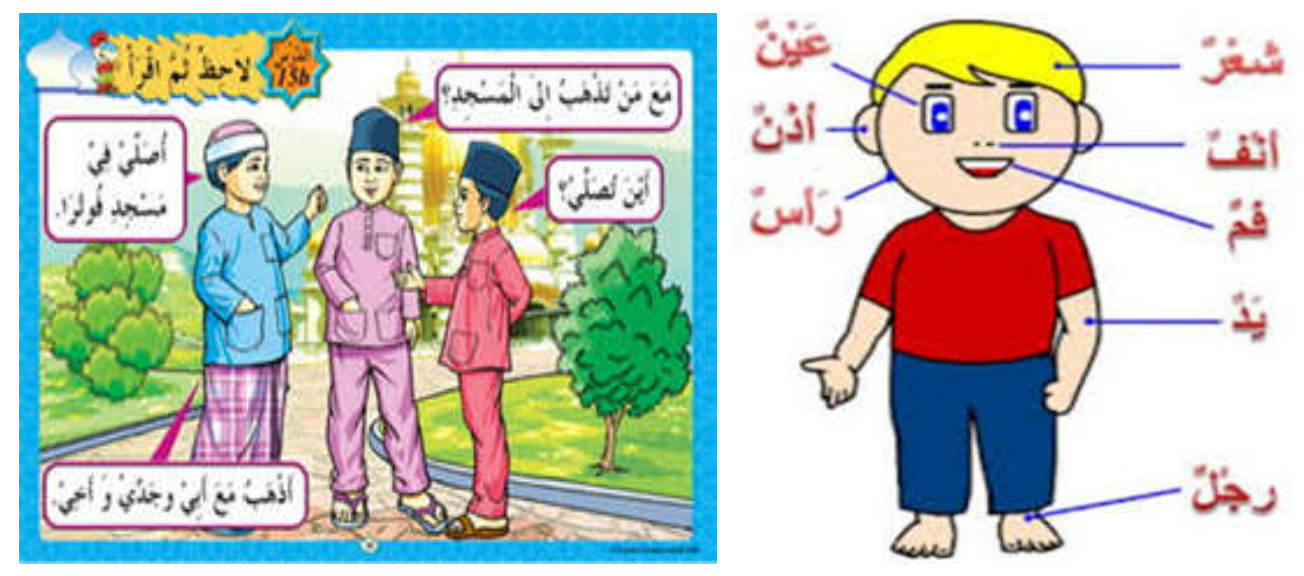

Kemudian peserta didik diperintahkan untuk mengkomunikasikan ide dan gagasan mereka berdasarkan gambar yang sesuai dengan menggunakan bahasa mereka sendiri. Kemudian guru memberikan penilaian dari Kosa kata (almufradât), Kelancaran (al-thalaqah), Ketelitian (al-diqqah), Pengucapan (attalaffudz), Intonasi (al-tanghim), Pemahaman (al-fahm).Untuk menguatkan materi pembelajaran, guru melakukan dialog antara siswa dan guru terutama pada saat memulai kegiatan belajar mengajar.

\begin{tabular}{|c|c|}
\hline Siswa Menjawab & Guru Mengabsen \\
\hline و عليكم السلام & السلام عليكم \\
\hline 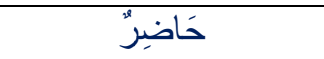 & أحمد! \\
\hline غَائبُبٌ & حَسَنَ! \\
\hline حَاضِرَةٌ & عَائشَُةَ" \\
\hline مَرِيْضَنة & فَاطِمَةٌُ! \\
\hline
\end{tabular}

Kegiatan ini dalam rangka menguatkan daya ingat peserta didik tentang kosa kata (mufradât) yang telah diajarkan, hendak terus dipraktekkan pada saat memulai pelajaran terutama pada saat guru mengabsen peserta didiknya.

\section{SIMPULAN}

Bahasa Arab sebagai bahasa Asing telah menjadi mata pelajaran wajib bagi Madrasah, ini menunjukkan bahasa Arab memiliki keistimewaan tersendiri dibandingkan mata pelajaran lain, dan juga sebagai fondasi ilmu dan sebagai alat komunikasi internasional. Bahasa Arab di Madrasah memiliki peran ganda, satu sisi sebagai bahasa agama pada sisi lain sebagai alat komunikasi. Sebagai bahasa agama, dengan bahasa Arab peserta didik bisa memahami Alquran dan hadis serta buku-buku bahasa Arab dengan baik, sedangkan pada sisi lain peserta didik dituntut untuk bisa berbahasa Arab. Dengan multi peran ini, guru dituntut agar 
mâhir (pintar) memilih dan menggunakan pendekatan yang tepat dalam pembelajaran agar tujuan dan ketrampilan yang hendak dicapai bisa terwujud. Salah satu pendekatan yang digunakan oleh guru adalah pendekatan ilmiah (scientifik approach), artinya guru harus terampil menggunakan media serta lingkungan belajar yang berbasis ilmiah dan kongkrit terutama pada saat mengajarkan mufradât (kosakata) bahasa Arab.

\section{DAFTAR PUSTAKA}

Acep Hermawan. 2013.Metodologi Pembelajaran Bahasa Arab. Bandung: PT Remaja Rosdakarya.

Kementerian Agama RI. 2014.Buku Guru Bahasa Arab Kelas IV Madrasah Ibtidaiyah Pendekatan Saintifik 2013. Jakarta. .2013.Buku siswaBahasa Arab Kelas 4 Madrasah Ibtidaiyah Pendekatan Saintifik 2013. Jakarta.

2014.Buku Guru Bahasa Arab Kelas I Madrasah Ibtidaiyah Pendekatan saintifik 2013. Jakarta. 2015.Buku Siswa Bahasa Arab Kelas 2 Madrasah Ibtidaiyah Pendekatan Saintifik Kurikulum 2013.Jakarta.

Hamid,M. Abdul. 2018.Pembelajaran Bahasa Arab Pendekatan, Metode, Strategi, Materi dan Media. Malang: UIN Malang Press.

Muna,Wa. 2011.Metodologi Pembelajaran Bahasa Arab Teori dan Aplikasi. Yogyakarta: Teras. 